\title{
Relevance of Business Ethics of Jain Philosophy in Modern Corporate World
}

\author{
Dr. Alka Jain \\ Assistant Professor cum Placement Officer, S. S. Jain Subodh Management Institute
}

\begin{abstract}
Followers of Jain philosophy practice five vows in their life per the choice (of limitations) of the practitioner. A layperson follows these vows patially, the vows are -अहिंसा(Non-violence),सत्य(Truthfulness), अचौर्य(Non-stealing), ब्रह्मचर्य (Chastity), परिग्रहपरिमाण(Limited non-possessiveness). Absolute level of these vows is observed by saints and nuns in Jain sects. Limited level of these vows observed by a common household person is the focus of our study.If this micro system of a Jain layperson's life style is adopted by the mankind at macro level then the whole world may achieve the target of an economy of satisfied consumers through the path of managerial excellence.Some may object that अपरिग्रह(the concept of non-possessiveness) may stop the growth of businesses as it may bring the level of buying motivation down. While on the contrary non-possessiveness will make the economy produce useful products and services only.Modern business strategies are working towards consumerism which is giving birth to an unrest in the society.
\end{abstract}

Keywords: Jainism, Jain philosophy, Business ethics, Ethics, Five vows, five small vows, truth, non-violence, non-stealing, nonpossessiveness,

\section{Research Problem}

1) Is Jain philosophy having a systematic set of business ethics?

2) Where are these ethics found in Jain literature?

3) Can these ethics work as control tools for an ethical economy?

4) Are they really relevant in modern business problem solutions?

\section{Scope of the Study}

The study focuses on business ethics found in five small vows of a Jain layperson. Though Jain literature is a treasure of ideas on ethics, but the author has limited her study to five small vows - Truth, non-violence, non-stealing, celibacy and non-possessiveness. Jain view on these five issues has been studied in the paper.

\section{What is Business Ethics?}

Philosopher William Lilie defines ethics as the normative science of the conduct of human beings living in the societya science which judges this conduct to be right or or wrong, good or bad etc. When the term business is attached to it, the two terms collectively stand for right and wrongs of the businesses. Hence we can say that Business ethics define code of conduct of human beings operating the business in an economy. According to S. Shyama Prasad, "The purpose of business is not simply to go on amassing wealth endlessly. Albeit profit making or wealth maximisation is a goal of every business but, it is not the end in itself. Money is the means to achieve something higher. Business should be driven by the motive of the welfare of the entire nation or at least of the society in which the business operates. However, in spite of varied opinions regarding the profit maximization motive of the organisations, there is a general agreement amongst the thinkers, academics and business managers that the business functions with the sanction of the society and hence they need to keep in mind the interest of at least the society, if not the entire mankind."

\section{Jaina Theory of Business Ethics}

Jaina Theory of Business Ethics is primarily a part of the quest of righteousness in businesses. The theory arrives at a consistent system of business principles that appear to be self evident.S. Shyama Prasad advocates that there is nothing wrong in an organisation seeking to make profit. However, when it makes substandard products or uses unfair means to gain market share or ignores its responsibility towards environment or goes out to destroy the competitors, it is unethical. As Mahatma Gandhi said, the world has enough for everyone's need but not for anyone es greed. This statement of Mahatma Gandhi seems to be based on his Jaina knowledge.

\section{Content}

We shall discuss the five small vows of a Jain Layperson and analyse how it displays ethics in a business or business transaction. These vows if implemented today may change the business environment from a profit oriented one to an ethical economic environment.We shall name the vow and then will see what restrictions are put on the practitioner of these vows.In practicing these five vows each vow has a companion of five don 'ts which are termed as ,atichara ${ }^{\text {ee }}$ practically these aticharas only constitute the Jaina ethics of business and hence If these restrictions act as ethical business control tool then we can conclude that the Jaina philosophy is relevant in solving modern business ethics problem.

\section{Non-Voilence and Business Ethics}

The element of non-violence (Ahimsa) establishes Jainism as an environment friendly philosophy. Water, fire, air, soil , all these elements of natural environment are considered alive and as per the vow of non-violence, no harm is done to these natural elements. Such an approach towards natural resources helps to save resources for the future and will help inhuman life security and continuity.

Five flaws of this voware बंधे - If I hurt someone by tying him tight (meaning kept someone in prison etc.), वहे (If I inflicted 


\section{International Journal of Science and Research (IJSR) \\ ISSN (Online): 2319-7064 \\ Index Copernicus Value (2013): 6.14 | Impact Factor (2014): 5.611}

pains and injuries to someone), छविच्छेए (If I injured someone physically or cut some part of the body), अइभारे - If I overloaded someone (with workload or weight etc.), भत्तनाणविच्छेए (Stopped someone from taking food and water). These five when applied to human resource or employees in an organization, they simply match with the requirement of an efficient human resource management approach.बंधे stands for not keeping the employees as slaves, वहेstands for life security of employees at work place, छविछेए means not hurting the employees physically at work, अईभारे means overload in physical sense and excess workload for employees beyond their capacity, भ त्तपाण विच्छे ए stands for basic needs of employees in terms of lunch break etc.

\section{Truth and Business Ethics}

In the vow of truth two violations carrying the element of law are :

These two restrictions in the conduct of a श्रावक(Jain lay man) may stop all forgeries and keep the economy free of any sort of unrest.

Truth is accepted as an essence of values in all religious philosophies but in Jainism all the vows are observed at three levels- 1. By thought (मन) 2. By speech (वचन) and 3. By actions (काया).Truth in speech and heart is responsible for social balance in economic and non-economic environment of businesses.Each and every vow of these five has a set of five flaws attached with them .We are mentioning only those in which we see some elements of business ethics. In the vow of truth such two flaws are :मोसोवयसे(not to make false statements)and कूडलेहकरणे(no false documentation). These two restrictions in the conduct of a business man may stop all forgeries and keep the economy free of any sort of unrest. All these restrictions on the actions of a layman establish proper documentation and fair measurement in businesses. In modern economies improper and false documentation is emerging as a major crime, which is emerging as a major problem in modern economies. The only solution to these economic problems is in this ethical approach to documentation. This solution can be the root of an ethical and transparent economy.

\section{Non-Stealing and Business Ethics}

In this vow the businessman does not steal anything, does not make anyone steal anything, does not support a stealing act. Any type of stealing of the wealth whose owner is not known to him is also considered as an act of stealing. Bribe is also another form of stealing. Restriction on fake ledgers also restricts dishonesty towards the law of states. Five flaws of this vow are :तेनाहडे( I will not take/buy anything stolen), तक्करप्पओगे( I will not support anyone who steals), विरुद्धरज्जाईकम्मे( I will not act against the rules of the state), कुडतुलकुड्डमाणे( I will not make any gap in the measurement what is mentioned and what is given,) and तप्पडिरुवगववहारे(I will deliver the same quality of goods that has been promised to the buyer).
Under these strict controls correct measurement of all the goods to be sold is the sellers's responsibility. This vow depicts that Jain philosophy insists on transparency and honesty in all business transactions. Once this vow is observed at macro level then this micro effort of transparent business can make the whole economy transparent and the whole world peaceful. Incorrect measurement of the goods less than prescribed on the package is considered a business cheating. To buy stolen goods at low rates is specifically prohibited in Jain scripture in third vow of non-stealing. Proper and on time payment of taxes is mandatory for a Jainbusinessman. To help someone in the act of stealing is also prohibited for a Jain layperson. The third flaw विरुद्धरज्जाईकम्मे(I will not act against the rules of the state), any act against the law of the state is prohibited for a business man .If this vow is followed by all citizens then growth of parallel or black economy will stop and transparency in businesses will be seen.As no stealing of tax,penalties will take place in the business environment.

\section{Celibacy (not to indulge in sexual activities) and Business Ethics}

Women in advertisements of goods are in bad shape today. They are being exposed like goods only in materialistic world. In this vow of chastity any woman other than your wife is not to touched, heard or seen with bad intention.If all the men observe the vow of one woman then our work places can be a safer place for the women of our society to work in.This way we can utilize the expense on the education of women who are $50 \%$ part of the society.At present rape, and exploitation of women at workplace keeps them away from offices in many cases. Sexual harassment will be stopped automatically if the women are safe in the economy.

\section{Parigrahparimaan (Non-Possessiveness) and Business Ethics}

If minimum basic need of the society is fulfilled first then there will be no place for hunger and poverty in the economy. In an economy, currency is used for business transactions. Right use of the currency keeps the elements of economy balanced and supports all products and services distribution to the consumers. Though currency is a supporting factor only but its planned management is highly required. Modern economist Karl Marx opines that attachment is the root of all rivalries and battles. Root of his statement can be seen in Mahavira's definition of parigraha Lord Mahavira's emphasis on distribution of excess resources to weaker sections of the economy has relevance in modern economic theories also. Roots of the theory of trusteeship given by Mahatma Gandhi can be seen in the philosophy of परिग्रह परिमाण (limited resources with one person is a desirable policy.) Many modern economists have realized now that our religious thoughts are the basis of our fiscal and monetary policies. This can be easily seen in countries following different religions having different monetary policies. 


\section{International Journal of Science and Research (IJSR) \\ ISSN (Online): 2319-7064}

Index Copernicus Value (2013): 6.14 | Impact Factor (2014): 5.611

Relevance of Jain Business Ethics in Modern Corporate World

Success of Jain businesses is emerging as a new fascinating subject for western researchers .Bob Keefe in his article „People Before Business, Technology ${ }^{\text {ee }}$ interviews the CEO Atul Jain ,of TEOCO Corp. U.S.A. and is intrigued when finds that unique business philosophy on values, religion and employees is the reason behind the success. It seems a new approach to Bob when during the interview Atul says, "It's a mindset that our employees are owners, not replaceable parts, and that we need to treat them with a degree of respect that you would treat any owner, "Atul Jain gives the credit of this unique successful business strategy to Jain philosophy, when he says, „I come from a very philosophical vantage point and I have access to a viewpoint

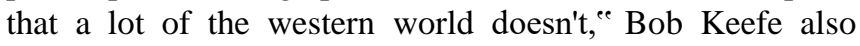
includes in the end of the article ,So far, Jain's unusual business philosophy has served the company well. Even in the lousy economy, the company's revenues grew by more than 25 percent last year, reaching \$47 million. Over the past three years, it has grown by 117 percent. ${ }^{\text {ee }}$ This statement is enough to prove what all we have been discussing that Jain economics and way of life and business is not a mere theory but a tested reality.

\section{Suggestions and Recommendations}

If a Jain system of business ethics is implemented then future managers of modern businesses can bring out a harmonious blend of our religious values with the modern management style to head a transparent, peaceful and content economy. In the age of globalization, we have to reaffirm faith in Indian ethos. The ethical principles of Jainism prescribe a code of conduct, which requires an individual to be an ideal person with nonviolence as the foundation of his life not only from the Indian context but also universally in this 21st century.

\section{Conclusion}

The Jaina theory has given a special direction to the evolutionary theories of business ethics. Strong ethics in business with strict implementation system for a Jain follower have the capacity to influence our business environment and taking towards the road of ethical business. The focus on good intention may bring harmony and transparency in the economy if applied in businesses. If this micro system of a Jain layperson's life style is adopted by the population at macro level then the whole world may achieve the target of an economy of satisfied consumers through the path of managerial excellence.

\section{References}

[1] William Lilie, ,An Introduction to Ethics ${ }^{\text {ee }}$ University Paperbacks, London,1964..

[2] T G Kalghatgi, „Jaina View of Life JainaSmritiSamraksakaSangha, Sholapur, 1984.

[3] Acharya Pujyapad, edited by PanditPhool Chand Shastri,Sarvartha Siddhi ${ }^{i e}$ BhartiyaGyanpeethPrakashan, New Delhi, 1997.
[4] HarendraShah, 'JainPratikraman in English"e Jain Centre of North California, 200.

[5] S. Shyama Prasad, Possessiveness and Ethical Business, Paper presented in the National Seminar on Application of Non-possession in Jainism held at JVBU, Ladnun, Rajasthan on 27-29, November, 2010 